the question of belief in God and of the efficacy of prayer should be freely discussed before, students; that there should be a deepening of the philosophical, ethical and art thought and feeling of the country; and that the foundation work along these lines should be laid at the state universities.

The example of the establishment of a college of education in the University of Minnesota by the legislature, upon the request of the teachers and normal schools of the state, for the purpose of training teachers for the high schools and the colleges, and complementing in advanced research work the normal schools, was unanimously approved as a solution of the question of the relation of the state universities to state normals.

The other questions before the conference were of local interest chiefly, and would not concern the country at large.

The national note, inherent in the very constitution of a state university, was struck in the following remarks made by President Northrop at the convocation of the University of Iowa held in honor of the visiting presidents:

Nothing else in the work of education has so interested me as the magnificent advance which the south is making in education. Under adverse circumstances, in the face of great difficulties, the educators of the south are showing a zeal and enthusiasm in their work, which can hardly be equaled elsewhere, and the fruits of which are most apparent and satisfactory. If there is any one thing that I especially long for, it is to see the national spirit revived everywhere, and north and south, alike, responding to the national sentiment, symbolized by our flag, and we can not have this unless we have ideals and purposes and plans somewhat in common.

And in no other department in life is it possible for us to have such ideals and purposes in common to so large a degree as in the work of education. In this, north and south are seeking the same results by like methods and it is possible for us all to have hearty sympathy in our work.

I appeal to you all, my brethren, representing, as you do, the educational forces in the great valley of the Mississippi, from Ohio to Colorado
- I appeal to you to assist and cheer and encourage our brethren of the South in every way you possibly can, in the interest of a truer union, a nobler patriotism, and a larger and more helpful education.

George E. MacLean

The State UnIversity of Iowa, IowA CTTY, November 10,1907

\section{THE AMERICAN CHEMICAL SOCIETY AND SECTION $C$}

The winter meeting of the society will be held at Chicago, Ill., December 31 to January 3 , inclusive. The meeting will be a joint meeting with Section C of the American Association for the Advancement of Science.

The Society of Biological Chemists will hold joint sessions with our Biological Section, and President Chittenden will preside over both.

The following persons have consented to preside over the sections and to aid in the preparations for the meeting:

W. D. Bigelow: Agricultural and Sanitary Chemistry.

R. H. Chittenden: Biological Chemistry.

William H. Ellis: Industrial Chemistry.

A. W. Browne: Inorganic Chemistry.

Julius Stieglitz: Organic Chemistry.

Herbert N. McCoy: Physical Chemistry.

Members desiring to present papers are requested to send titles and brief abstracts to one of these persons, or to the secretary of the society.

Titles of all papers received before November 25 will appear on the preliminary program, which, with announcements, will be sent to all members on November 30 . The final program will be sent only to those members signifying their intention of being present at the meeting. No title can be placed on the final program that is received later than December 15. In the preparation of papers for presentation, a clear and concise statement of results which have been obtained, and of conclusions reached, should alone be given. All essential and technical detail should be reserved for the published paper, as the time that can be allotted is lim- 
ited, and papers given in this manner are always much better received.

The current year has been remarkably successful for The American Chemical Society, and the membership instead of falling off when the dues were increased to $\$ 8$ has been largely augmented, and by the end of the year will be approximately thirty-five hundred. Chemical Abstracts thus far has exceeded all expectations, and some of the earlier numbers have had to be reprinted to meet the demand. This result is especially encouraging when we remember that a printers' strike and other delays, beyond the control of the editor and outside of his office, have made its appearance annoyingly irregular. The attention of members is called to the fact that this matter has received most careful and business-like attention, and most positive assurances have been received that the new publishers will issue both Journal and Abstracts on time beginning 'with the new year.

The summer meeting at Toronto was, eminently successful and will be ever remembered by those present. Prospects for the Chicago meeting this winter are very bright, and all members of the society are urged to make every effort to be present. The friendships formed and "esprit de corps" gained at these meetings are of inestimable benefit to the individual and to the profession.

During the year a number of important committees have been appointed and reports made, all of which are published in the proceedings. The offices of editor and secretary have been separated, an associate editor has been engaged whose time is given to the Journal and Abstracts, and funds for a stenographer have been voted to the editorial office.

Local sections have been established with headquarters at Syracuse, N. Y., St. Louis, Mo., and Madison, Wis.

President Bogert has been especially interested and active in considering the needs and desires of our industrial chemists, and a committee of prominent chemists representing important lines of industry and headed by William D. Richardson, of Swift \& Co., Chi- cago, is now considering the publication of a Journal of Industrial Chemistry for the benefit of our members. Their success will depend largely upon the size of our membership, as funds are required for all such undertakings.

Charles L. Parsons, Secretary

\section{THE AMERICAN PHYSIOLOGICAL SOCIETY}

The American Physiological Society will hold its twentieth annual meeting in Chicago, during convocation week, beginning on December 31, 1907. Members of the society are requested to inform the secretary at their earliest convenience whether they intend to be present. The society will hold joint sessions with the American Society of Biological Chemists and with Section K-Physiology and Experimental Medicine-of the American Association for the Advancement of Science. The place of meeting will be Room 25, Physiology Building of the University of Chicago. Titles of communications to be offered at the meeting may be sent to the secretary. Inquiries regarding apparatus and other necessities for demonstrations may be addressed to Professor A. J. Carlson (for physiological apparatus), or Professor A. P. Mathews (for chemical apparatus), at the University of Chicago. Further details regarding the headquarters of the society and other local arrangements will be announced later.

\section{Lafayette B. Mendel, Secretary}

\section{Sheffietd Scientific School, YALE UNIVERSITY}

\section{SCIENTIFIC NOTES AND NEWS}

The committee on policy of the American Association for the Advancement of Science held a meeting in New York City on November 19. All the members of the committee were present, namely, President R. S. Woodward, chairman; Dr. William H. Welch, retiring president of the association; Professor Edward L. Nichols, president-elect; Dr. L. O. Howard, permanent secretary; Professor J. McK. Cattell, Professor H. L. Fairchild and Professor Charles L. Minot. The business 